\title{
Influence of Irrigation Water Regimes and Patterns of Nitrogen Placement Combined with Soil Compaction on Wheat
} (Triticum aestivum L.) Growth

\author{
Abd-Elaziz, M.H.M.; I.N. Nassar; M.A. Gameh and S.A.H. Selmy
}

${ }^{1}$ Soils \& Water Dept., Faculty of Agriculture, Assiut Univ.

${ }^{2}$ Soils \& Water Dept., Faculty of Agriculture, Damanhur Univ.

Received on: $28 / 2 / 2019$

Accepted for publication on:13/3/2019

\section{Abstract:}

Irrigation management and pattern of nitrogen application associated with soil compaction are critical factors in wheat growth. This study aimed to evaluate the effect of irrigation regimes and patterns of nitrogen fertilizer placement in presence of soil compacted layer on some wheat growth parameters. Germination percentage, plant height, pike length, 10-spike weight, total yield and grain yield were measured. Sandy loam lysimeter $(0.60 \times 1.0$ and $0.55 \mathrm{~m}$ deep) experiments were conducted in a split-plot design with three replications in the experimental agricultural station of Assiut University, for two seasons 2016/2017 and $2017 / 2018$. The upper layer $(0.15 \mathrm{~m})$ in some lysimeters was compacted moderately with a bulk density of $1580 \mathrm{~kg} / \mathrm{m}^{3}$ and used for nitrogen placement, while the other soil lysimeter possessed a bulk density of $1420 \mathrm{~kg} / \mathrm{m}^{3}$. The experiment was consisted of two irrigation regimes viz, field capacity (F.C.) and saturation capacity (S.C.) as main plots and five patterns of nitrogen placement and soil compaction: mixed fertilizer in un-compacted surface layer (F. IN UN-C.S.L.), placed fertilizer above compacted surface layer (F. ABOVE C.S.L.), placed fertilizer beneath compacted surface layer (F. BENEATH C.S.L.), mixed fertilizer in compacted surface layer (F. IN C.S.L.), and placed fertilizer above uncompacted surface layer (F. ABOVE UN-C.S.L.) as sub plots. The results indicated that irrigation at F.C. improved some of wheat growth parameters such as germination percentage, 10-spike weight, total yield and grain yield compared with irrigation at the S.C. The differences in the values these growth parameters were significant to high significant under the patterns of nitrogen placement and compactions. Also, it was obvious that moderate compaction, i.e. bulk density of $1580 \mathrm{~kg} / \mathrm{m}^{3}$, enhanced the studied growth parameters except spike length and grain yield in comparison to non-compacted condition. Generally, some growth parameters of wheat were affected positively under compacted soil layer under F.C. Accordingly, the results recommend that for improvement wheat growth grown on sandy loam soil it is preferable to use irrigation at filed capacity with mixing of nitrogen on the compacted surface soil layer.

Keywords: Wheat, lysimeter, irrigation, compaction, nitrogen placement, and growth parameters.

\section{Introduction}

Water and nutrients supply are the main factors controlling the productivity of irrigated agriculture. Also, type of cultivated plants and water regime are essential factors controlling the yield productivity. Improving the use efficiencies of water and nitrogen is the target of good management and becomes crucial in 
arid and semi-arid regions where water resources are limited. Generally, the high efficiency is mandatory especially for saving water, increasing soil productivity and protecting the environment.

Wheat (Triticum aestivum L.) is a main source of plant protein in Egypt as in many other parts of the world. Egypt suffers from a considerable gap between its national production and consumption. To solve this problem, the Egyptian government should extend the agricultural area by reclaiming desert land and cultivate it with wheat., Also, the Egyptian scientists are trying to do their best to enhance water use efficiency. Water demand by wheat is variable because it depends on climate, wheat species, soil texture, and irrigation methods. Additionally, in dryland irrigated agriculture; nitrogen fertilization becomes the most limiting factor for crop productivity. Under these conditions, the efficiency of using both irrigation water and nitrogen is often low and depends largely on the method of application (Bar-Yosef, 1999).

Doorenbos and Kassam (1979) reported that, for high yield of wheat, crop water requirements are ranged from 3200 to $5200 \mathrm{~m}^{3} / \mathrm{ha}$ depending on climate and length of the growth period. Mohamed (2007) found that the corresponding applied waters for cultivated wheat under Assiut conditions, Egypt, using three irrigation systems which are surface, sprinkler and drip irrigation were approximately 3211, 2806 and $2489 \mathrm{~m}^{3} /$ fed respectively. Also, for the three irrigation regimes $(25,50$ and $75 \%$ of available soil moisture) using surface and sprinkler methods, the seasonal irrigation water applied values were $3934.98,3445.26$ and $2900.52 \mathrm{~m}^{3} / \mathrm{fed}$ under surface irrigation, while it was 2612.4, 2224.32 and $1918.14 \mathrm{~m}^{3} / \mathrm{fed}$ under sprinkler irrigation system.

Kharrou et al., (2011) conducted a field experiment during the 2004 - 2005 season in Haouz area in Morocco for wheat production using surface and drip irrigations. This experiment indicated that drip irrigation was more efficient with $20 \%$ of water saving and gave higher wheat yield $(+28 \%)$ in comparison with surface irrigation. Geerts and Raes (2009) reported that an increase in crop water productivity can occur under deficient irrigation (DI) of wheat without causing severe yield reductions. Tadayon et al., (2012) studied the effects of amounts of supplemental irrigation at growth stages and application of nitrogen fertilizer on grain yield and water productivity of wheat cultivars for 2 years. Their results revealed that there are relationship between grain yield and water productivity, Nitrogen application showed a positive correlation $\left(\mathrm{r}^{2}=0.88\right)$ between grain yield, water productivity, and nitrogen application with available water under their experiment at condition.

Zhang et al., (2017) evaluated the effect of irrigation and nitrogen application on the grain yield, protein content and amino acid composition of winter wheat $(2012 / 2015)$ in the North China Plain. The results showed that irrigation at jointing stage and at jointing plus a thesis stages improved grain yield with mean of 12.79 and $18.65 \%$ respectively, across three cropping seasons 
compared with no irrigation treatment.

A field experiment was carried out by Shirazi et al., (2014) to evaluate the effect of irrigation regimes and nitrogen levels on the growth and yield of wheat cv. Kanchan (Triticum aestivum_L.). The experiment includes two factors such as four irrigation regimes ((no irrigation), $100 \mathrm{~mm}$ at 30 days after sowing, $200 \mathrm{~mm}(100 \mathrm{~mm}$ at 30 days + $100 \mathrm{~mm}$ at 45 day), and $300 \mathrm{~mm}$ (100 $\mathrm{mm}$ at 30 days $+100 \mathrm{~mm}$ at 45 days $+100 \mathrm{~mm}$ at 60 days)) and four nitrogen levels $(00,80,100$, and 120 $\mathrm{kgNha}-1)$. Maximum grain yield of $2.27 \mathrm{t} \mathrm{ha}^{-1}$ was obtained by the application of $200 \mathrm{~mm}$ irrigation treatment. The combination of $200 \mathrm{~mm}$ irrigation and $120 \mathrm{~kg} \mathrm{~N} / \mathrm{ha}^{-1}$ was the best treatment for optimal production of wheat.,

Soil compaction can result in crop yield reduction by its effects on water infiltration into the soil, seedlings emergence, roots penetration and uptaking of nutrients and water (Pengthamkeerati et al., 2006). Oussible et al., (1992) studied the effect of subsurface compaction on the root and shoot growth, grain yield, and grain yield components of wheat (Triticum aestivum L.) by conducted field experiments (1982 and 1983) using a clay loam soil (Typic Calcixerolls). Their results indicated that the grain and straw yields were decreased as a result of compaction by a 12 to $23 \%$ and 9 to $20 \%$ respectively, compared to un-compacted soil. The decrease in yield was accompanied by a consistent reduction in the number of shoots per unit area. But number of kernels per spike, kernels weight, plant height, leaf area and dry matter per shoot were unaffected. They attributed the decrease in shoot number to a limitation in the amount of available soil nitrogen to the roots.

Similar subsurface compaction studied by Ishaq et al., (2001) for wheat (Triticum aestivum L.). They reported that the soil compaction treatment resulted in a reduction in the grain yield of wheat by a $38 \%$ during 1997-1998 season and 8\% during 1998-1999 season. While the straw yield was affected by a decrease up to $12 \%$ in 1997-1998 season only where it was not affected in 1998-1999 season. Also, results showed that the subsoil compaction adversely affected soil physical properties, which decreased yields as well as water and nutrient use efficiencies by crops. Bokken et al., (1987) investigated effects of soil compaction by tractor traffic on a loam soil on wheat yield. Tractor traffic on wet soil reduced the wheat yield by about $25 \%$, and increased the N-loss through denitrification by a factor of 3-4. Neither of these parameters was affected by tractor traffic at low soil moisture content.

Lipiec et al., (2003) showed that an increase in soil compactness results in decreased the root size of barley, the high density of roots in the upper soil, lower rooting depth and a greater distance between the nearest roots. Insufficient water supply decreased in compacted soil whereas the water use efficiency by the roots increased. Both nutrient uptake and effectiveness of fertilization is reduced by soil compaction. According to the literatures cited, the objective of the present work is to evaluate the 
wheat growth under two levels of irrigation regime (field and saturation capacities) combined with five patterns of compaction and ammonium nitrate placements.

\section{Materials and Methods}

Lysimeter experiments were conducted during two successive growth seasons (2016/2017 and $2017 / 2018$ ) to evaluate the growth of winter wheat under different irrigation regimes and soil compaction. These experiments were carried out at the experimental agricultural station at Assiut University with GPS coordinates of $27^{\circ} 11^{\prime} 16^{\prime \prime} \mathrm{N}$ and $31^{\circ} 10^{\prime}$ $13^{\prime \prime} \mathrm{E}$. The soil lysimeter experiments were conducted in open agriculture field with exposing the upper surface of the soil to the natural atmosphere throughout the growth periods of the two seasons.

The lysimeters were constructed from one type disturbed soil (0.60x1.0 and $0.55 \mathrm{~m}$ depth) with or without compaction using wooden boxes $(0.60 \times 1.0$ and $0.60 \mathrm{~m}$ depth). Prior to soil lysimeter packing, the interior sides of the wooden boxes are lined with a protective layer of polystyrene to avoid water leaking. The soil materials were mixed well then packed into wooden boxes with 0.55 $\mathrm{m}$ thickness and its surface was 0.05 $\mathrm{m}$ from the upper edges of boxes for all lysimeters. Two patterns of soil packing were used. One of them is packed uniformly for the whole thickness of the soil lysimeter $(0.55)$ at a bulk density of $1420.0 \mathrm{~kg} / \mathrm{m}^{3}$. While, the other pattern was packed into two layers with different bulk densities, where the upper soil layer $(0.15 \mathrm{~m})$ was compacted layer at a bulk density of $1580 \mathrm{~kg} / \mathrm{m}^{3}$, but the lower soil layer $(0.40 \mathrm{~m})$ was uncompacted and was packed at a bulk density of $1420.0 \mathrm{~kg} / \mathrm{m}^{3}$. The compaction of soil was achieved using a heavy load metal part. The used soil in these experiments is classified as Typic Torrifluvents with sandy loam texture $($ sand $=64.81 \%$, silt $=15.96 \%$ and clay $=19.23 \%$ ), More details on the characteristics of this soil were as shown in Table (1)

Table 1. Some soil characterizations

\begin{tabular}{|c|c|c|c|}
\hline Property & value & Property & value \\
\hline $\mathrm{pH}(1: 5)$ & 7.71 & $\mathrm{Ks}\left(\mathrm{m} \mathrm{s}^{-1}\right)$ (compacted) & $5 \times 10^{-6}$ \\
\hline EC. $(1: 1) \mathrm{dS} / \mathrm{m}$ & 1.01 & $\theta \mathrm{i}$ (initial water content) $\left(\mathrm{m}^{3} \mathrm{~m}^{-3}\right)$ & 0.0287 \\
\hline Organic matter $(\%)$ & 0.26 & Clay $(\%)$ & 19.23 \\
\hline $\mathrm{CaCO} 3 \%$ & 2.61 & Sand ( \% ) & 64.81 \\
\hline Initial available $\mathrm{NH}_{4}, \mathrm{ppm}$ & 33.23 & Silt $(\%)$ & 15.96 \\
\hline Initial available $\mathrm{NO}_{3}$, ppm & 66.45 & Soil texture & Sandy loam \\
\hline ps (real density) $\left(\mathrm{kg} \mathrm{m}^{-3}\right)$ & 2590.0 & Saturation $\left(\mathrm{m}^{3} \mathrm{~m}^{-3}\right)$ & 0.350 \\
\hline$\rho$ (bulk density) $\left(\mathrm{kg} \mathrm{m}^{-3}\right)$ (un-compacted) & 1420.0 & Field capacity $\left(\mathrm{m}^{3} \mathrm{~m}^{-3}\right)$ & 0.202 \\
\hline$\rho$ (bulk density) $\left(\mathrm{kg} \mathrm{m}^{-3}\right)$ (compacted) & 1580.0 & Wilt Point $\left(\mathrm{m}^{3} \mathrm{~m}^{-3}\right)$ & 0.106 \\
\hline Ks $\left(\mathrm{m} \mathrm{s}^{-1}\right)$ (un-compacted) & $1.23 \times 10^{-5}$ & Available water $\left(\mathrm{m}^{3} \mathrm{~m}^{-3}\right)$ & 0.096 \\
\hline
\end{tabular}

Irrigation of the lysimeters was carried out using drip irrigation system that is available at the experimental site. Two irrigation regimes were used for irrigation during the growth seasons. The wheat seeds (Triticum aestivum vulgar, cv Sids 1) were planted at rate of $70 \mathrm{~kg} / \mathrm{fed}$ in two parallel lines. Black polyethylene plastic pipe of $16 \mathrm{~mm}$ diameter was 
fixed on the lysimeters and 2 drippers were used with discharge rate of $4 \mathrm{~L}$ $\mathrm{h}^{-1}$, on each and the drip irrigation operating pressure was 1.5 bars. The water meter was used to adjust this process. Moisture regime of saturation capacity (S.C) was maintained between 0.350 and $0.198 \mathrm{~m}^{3} \mathrm{~m}^{-3}$ and field capacity (F.S) was maintained between 0.202 and $0.157 \mathrm{~m}^{3} \mathrm{~m}^{-3}$. Irrigation timing was defined according to the irrigation regime, the growth stage of wheat and the daily potential evapotranspiration $\left(\mathrm{ET}_{0}\right)$ under Assiut governorate conditions. Weekly pan evaporation, $\mathrm{ET}_{0}$, and mean temperature were obtained from an onsite weather station. (Table 2).
Nitrogen, Phosphorus and potassium fertilizers were added according to the recommended rates by the Egyptian Ministry of Agriculture, at planting time. Phosphorus fertilizer in the form of super phosphate $(15 \%$ $\mathrm{P}_{2} \mathrm{O}_{5}$ ) was added at the rate of $100 \mathrm{~kg}$ $\mathrm{P}_{2} \mathrm{O}_{5} /$ fed while, potassium fertilizer in the form of potassium sulphate $(50 \%$ $\mathrm{K}_{2} \mathrm{O}$ ) was added at a rate of $50 \mathrm{~kg}$ $\mathrm{K}_{2} \mathrm{O} /$ fed. Nitrogen fertilizer in form of ammonium nitrate $(33.5 \% \mathrm{~N})$ was added as one dose to the soil lysimeters in five application patterns at planting at rate of $150 \mathrm{~kg} \mathrm{~N} \mathrm{Fed}^{-1}$. Additionally, drip fertigation was performed using irrigation water containing $28.37 \mathrm{ppm}$ of nitrogen.

Table 2. Climate data through the growth season $(2016 / 2017-2017 / 2018) *$,

\begin{tabular}{|c|c|c|c|c|c|c|}
\hline \multirow{2}{*}{ Month } & \multicolumn{2}{|c|}{$\mathbf{T} \mathbf{m a x}\left(\mathbf{c}^{\mathbf{0}}\right)$} & \multicolumn{2}{c|}{$\mathbf{T} \mathbf{m i n}\left(\mathbf{c}^{\mathbf{0}}\right)$} & \multicolumn{2}{|c|}{$\left.\mathbf{E T}_{\mathbf{0}} \mathbf{( m m} / \mathbf{d a y}\right)$} \\
\cline { 2 - 7 } & 2016 & 2017 & 2016 & 2017 & 2016 & 2017 \\
\hline December & 19.9 & 23.70 & 6.3 & 7.90 & 3.70 & 1.53 \\
\hline January & 19.3 & 20.48 & 5.3 & 3.59 & 3.73 & 1.74 \\
\hline February & 20.5 & 25.50 & 6.3 & 8.02 & 4.33 & 2.44 \\
\hline March & 25.3 & 30.94 & 11.0 & 10.51 & 6.44 & 3.66 \\
\hline April & 31.3 & 33.37 & 15.5 & 14.06 & 8.59 & 4.84 \\
\hline
\end{tabular}

*Meteorological Station at Assiut University

The compaction and ammonium nitrate placement patterns can be summarized as shown in Table (3). Two irrigation regimes meanly, field capacity (F.C.) and saturation capacity (S.C.) were used as the main plots while, five patterns of ammonium nitrate placement and soil compaction, which were mixed fertilizer in uncompacted surface layer (F.IN UNC.S.L.), fertilizer placed above compacted surface layer (F.ABOVE C.S.L.), fertilizer placed beneath compacted surface layer (F. BENEATH C.S.L.), fertilizer was mixed with the surface layer then compacted (F.IN C.S.L.), and placed fertilizer above un-compacted surface layer like the farmer practices (F.ABOVE UN-C.S.L.) were used as sub plots. According to irrigation regimes and ammonium nitrate application patterns, ten treatments were used and each had three replicates

The wheat growth parameters include germination percentage, plant height, pike length, 10-spike weight, total yield, grain yield, grain nitrogen and straw nitrogen contents were measured. Data obtained from these measurements were analyzed statistically for analysis of variance (ANOVA) following the method described by Gomez and Gomez (1984). 
Table 3. Patterns of nitrogen placements with compacted soil layers

\begin{tabular}{|l|l|}
\hline \multicolumn{1}{|c|}{ Pattern } & \multicolumn{1}{c|}{ Abbreviation } \\
\hline Fertilizer were mixed in un-compacted surface layer & F. IN UN-C.S.L. \\
\hline Fertilizer were placed fertilizer above compacted surface layer & F. ABOVE C.S.L. \\
\hline Fertilizer were placed fertilizer beneath compacted surface layer & F. BENEATH C.S.L. \\
\hline Fertilizer were mixed fertilizer in compacted surface layer & F. IN C.S.L. \\
\hline Fertilizer were placed fertilizer above un-compacted surface layer & F. ABOVE UN-C.S.L. \\
\hline
\end{tabular}

\section{Results and Discussion}

\section{Germination percentage}

The germination process of wheat seeds is complex and can be affected by many environmental factors such as temperature, water availability, oxygen, light, substrate, maturity and physiological age of the seed. Generally, the minimum water content required in the wheat grain for germination is $35 \%$ to $45 \%$ by weight (Evans et al., 1975). Conversely, germination is generally impeded by excess of moisture mainly due to a restriction of oxygen availability.

Germination percentages for all treatments through the two growth seasons of 2016/2017 and 2017/2018 are shown in Figure (1) and Table (4). The two growth seasons will be referred as $\mathrm{A}$ for the $1^{\text {st }}$ season and $\mathrm{B}$ for the $2^{\text {nd }}$ season in all figures. The germination percentages under F.C. were superior in comparison to the irrigation at S.C. under all compaction and ammonium nitrate placement patterns (Figure1). The germination percentages under F.C was 1.29$50.89 \%$ with an average of $14.8 \%$ greater than S.C. $1^{\text {st }}$ season and from 3.29 to $58.75 \%$ with an average of $15.5 \%$ greater than S.C. in the $2^{\text {nd }}$ season among of all treatment. Also, the highest increase was record in F. ABOVE C.S.L. treatment, while the lowest one was observed in F. IN C.S.L. treatment for both season (Table 4).

The results indicated that the treatment of F. BENEATH C.S.L. possessed the greatest germination percentage (95.9\%and 94\%) under F.C regime, while the treatment F. ABOVE C.S.L. produced the lowest germination percentage $(56 \%$ and $54.3 \%$ ) under S.C. regimein the both season. These variation in the germination percentages under the F.C and S.C. might attribute to soil air and water content for seed germination, i.e. at saturation capacity, the air content is null while at field capacity the aeration capacity is suitable for respiration that enhance the seed germination.

In the present study, analysis of the data indicated that irrigation regimes and, the combined pattern of nitrogen placement and compaction had a high significant $(\mathrm{p}<0.01)$ effects on the germination percentages for the two growth seasons (Table 4). Ashraf and Abu-Shakra (1978) found that the seeds of four wheat cultivars germinated when on soil their moisture content was approximately 50\% on a fresh weight basis. 
Table 4. Effect of irrigation regimes and fertilization-compaction patterns on the germination percentage for two successive growth seasons (2016/2017 and 2017/2018.

\begin{tabular}{|l|c|c|c|c|c|c|}
\hline Plant characters & \multicolumn{6}{|c|}{ Germination (\%) } \\
\hline Seasons & \multicolumn{3}{|c|}{$\mathbf{2 0 1 6 / 2 0 1 7}$} & \multicolumn{3}{c|}{$\mathbf{2 0 1 7 / 2 0 1 8}$} \\
\hline Treatment type & $\begin{array}{c}\text { Field } \\
\text { Capacity }\end{array}$ & $\begin{array}{c}\text { Saturation } \\
\text { Capacity }\end{array}$ & Average & $\begin{array}{c}\text { Field } \\
\text { Capacity }\end{array}$ & $\begin{array}{c}\text { Saturation } \\
\text { Capacity }\end{array}$ & Average \\
\hline F. IN UN-C.S.L. & 87.93 & 77.59 & 82.76 & 89.70 & 80.50 & 85.10 \\
\hline F. ABOVE C.S.L. & 84.48 & 56.03 & 70.26 & 86.20 & 54.30 & 70.25 \\
\hline F. BENEATH C.S.L. & 95.87 & 85.92 & 90.90 & 94.00 & 86.20 & 90.10 \\
\hline F. IN C.S.L. & 86.21 & 85.06 & 85.63 & 87.90 & 85.10 & 86.50 \\
\hline F. ABOVE UN-C.S.L. & 64.66 & 60.34 & 62.50 & 67.20 & 62.10 & 64.65 \\
\hline Average & 83.83 & 72.99 & 78.41 & 85.00 & 73.60 & 79.30 \\
\hline \multicolumn{1}{|c|}{ F } & Irrigation & Treat & Inter & Irrigation & Treat & Inter \\
\hline \multicolumn{1}{|c|}{ L.S.D.(0.05) } & & 2.97 & $* *$ & $* *$ & $* *$ & $* *$ \\
\hline
\end{tabular}

* Significant at the 0.05 level, ** Significant at the 0.01 level

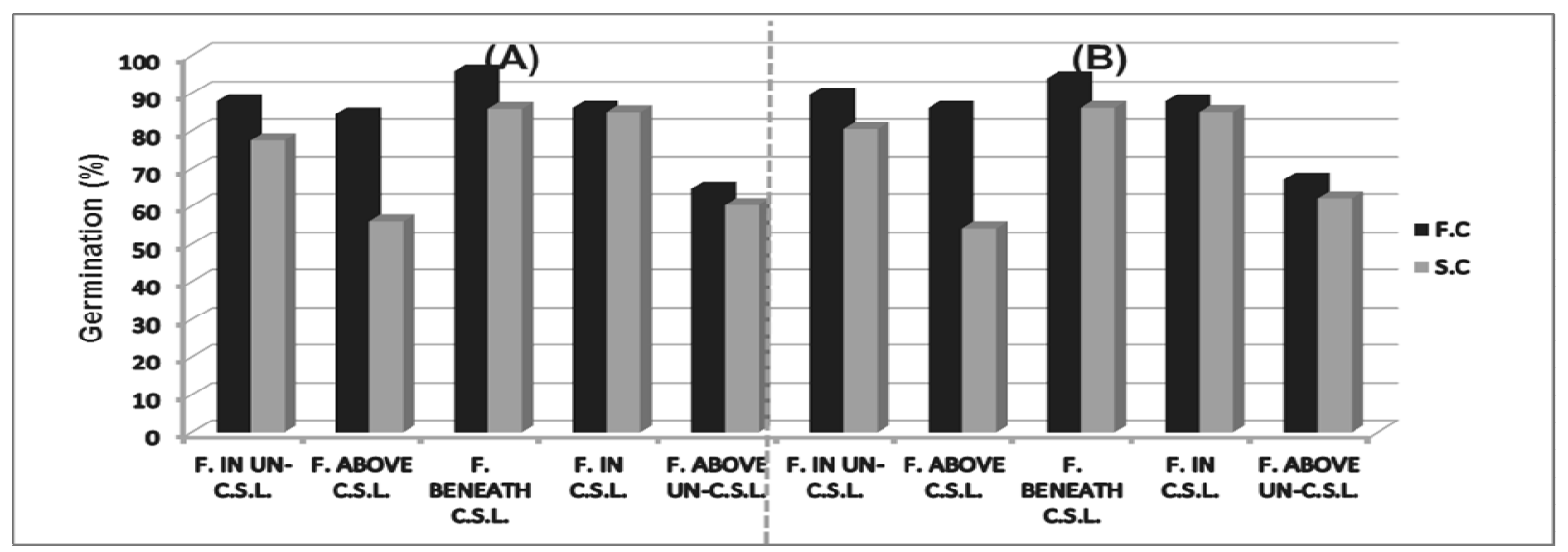

$\mathrm{F}=$ Fertilizer $; \mathrm{C}=$ Compacted $; \mathrm{S}=$ Surface $\quad \mathrm{L}=$ Layer $; \mathrm{A}=1^{\text {st }}$ season and $\mathrm{B}=2^{\text {nd }}$ season.

Figure (1): Germination percentages under field capacity (F.C.), saturation capacity (S.C.), different patterns of compactions and fertilization placement

\section{Plant height}

Wheat plant height under all treatments for first and second seasons was as shown in Figure (2). and Table (5). The results showed that the plant height behaved similarly under both growth seasons. Where Irrigation at saturation capacity regime gave greater plant height (average of $98.3 \mathrm{~cm}$ ) compared with those obtained at filed capacity regime (average of $91.8 \mathrm{~cm}$ ). During the second season, the plant heights where greater than in the first season. F. BENEATH C.S.L.and F. IN C.S.L. treatments recorded the highest value of plant higher $(105 \mathrm{~cm})$ under S.C. in the second season. While, the lowest value of plant height $(86.2 \mathrm{~cm})$ was observed in F. IN C.S.L. treatment under F.C.in the first season. Similar results were reported by AlMolhem (2016) and Saleem et al., (2007). Al-Molhem (2016) found that irrigation of wheat at $100 \%$ of the evapotranspiration potential had the greatest plant height in comparison to irrigation at $60 \%$ or $80 \%$ regimes, and Saleem et al., (2007) reported that three irrigations during the whole season of growth gave the greatest 
wheat plant height in comparison to zero or four irrigations

The present study showed that the patterns of nitrogen placements with soil compaction affected the plant height. incorporation of the nitrogen fertilizer in the upper $0.15-\mathrm{m}$ layer at S.C. regime possessed the greatest plant higher. Irrigation at the F.C. with the nitrogen placement and compaction patterns affected wheat heights significantly (Table 5). Irrigation at the saturation capacity at the corresponding fertilization and com- paction show significant effects on the plant height (Table 5).

Generally, patterns fertilizer application patterns did exhibit small variations on wheat shoot heights under both irrigation regimes. Atwell (1990) studied wheat \{Triticum aestivum L. cv. Eradu) growth in the field on a deep loamy sand soil which had either a compact soil layer (compact soil) between 10 and $55 \mathrm{~cm}$ depth or a deep-tilled profile (loosened soil). Between 33 and 62 day after sowing, shoots grow more slowly and had fewer tillers on the compact soil.

Table 5. Effect of irrigation regimes and fertilization-compaction patterns on Plant height $(\mathrm{cm})$ percentage for two successive growth seasons $(2016 / 2017$ and 2017/2018).

\begin{tabular}{|l|c|c|c|c|c|c|}
\hline Plant characters & \multicolumn{5}{|c|}{ Plant height (cm) } \\
\hline Seasons & \multicolumn{3}{|c|}{$\mathbf{2 0 1 6 / 2 0 1 7}$} & \multicolumn{3}{c|}{$\mathbf{2 0 1 7 / 2 0 1 8}$} \\
\hline Treatment type & $\begin{array}{c}\text { Field } \\
\text { Capacity }\end{array}$ & $\begin{array}{c}\text { Saturation } \\
\text { Capacity }\end{array}$ & Average & $\begin{array}{c}\text { Field } \\
\text { Capacity }\end{array}$ & $\begin{array}{c}\text { Saturation } \\
\text { Capacity }\end{array}$ & Average \\
\hline F. IN UN-C.S.L. & 86.17 & 100.50 & 93.33 & 94.67 & 101.70 & 98.17 \\
\hline F. ABOVE C.S.L. & 90.67 & 99.17 & 94.92 & 97.67 & 104.00 & 100.80 \\
\hline F. BENEATH C.S.L. & 93.00 & 97.17 & 95.08 & 90.33 & 105.00 & 97.67 \\
\hline F. IN C.S.L. & 95.50 & 97.67 & 96.58 & 92.67 & 105.00 & 98.83 \\
\hline F. ABOVE UN-C.S.L. & 86.83 & 97.25 & 92.04 & 90.33 & 101.00 & 95.67 \\
\hline Average & 90.43 & 98.35 & 94.39 & 93.13 & 103.30 & 98.23 \\
\hline \multicolumn{1}{|c|}{ F } & Irrigation & Treat & Inter & Irrigation & Treat & Inter \\
\hline L.S.D.(0.05) & $*$ & Ns & ns & $*$ & $*$ & $*$ \\
\hline
\end{tabular}

* Significant at the 0.05 level, ** Significant at the 0.01 level

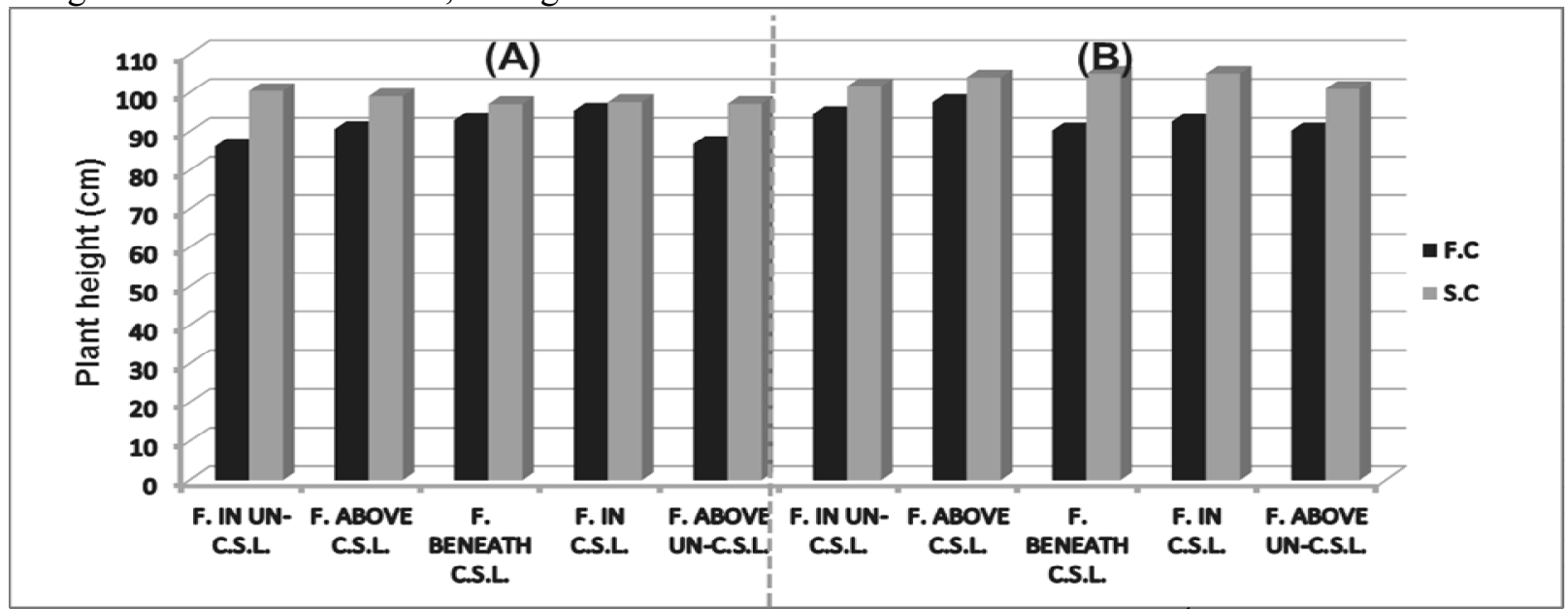

$\mathrm{F}=$ Fertilizer; $\mathrm{C}=$ Compacted; $\mathrm{S}=$ Surface; $\mathrm{L}=$ Layer; $\mathrm{A}=1^{\text {st }}$ season and $\mathrm{B}=2^{\text {nd }}$ season.

Figure (2): The plant height at harvesting under field capacity (F.C.), saturation capacity (S.C.), different patterns of compactions and $\mathrm{N}$ fertilization placement. 


\section{Spike length}

The data of spike length as a function of irrigation regimes, different nitrogen placements and compactions patterns for the two seasons are presented in Figure (3). Values of spikes length varied form 9.7 to 11.5 $\mathrm{cm}$ under all treatments for both tow seasons. The spike length as an average were 10.4 and $11.3 \mathrm{~cm}$ under F.C. and S.C. irrigation regime respectively in the first growth season. The corresponding spike length in the second growth season was $10.8 \mathrm{~cm}$ for both irrigation regimes (Table 6). The spikes length differed little between the two irrigation regimes. The difference in spikes length under F.C. and S.C. ranged between zero to 1.3 $\mathrm{cm}$. Where the greatest difference $(1.3 \mathrm{~cm})$ was recorded under F. BENEATH C.S.L. in the first season, while the lowest one (zero) was observed under F. IN C.S.L. in the second season.

The values of spike length were increased under F.C. regime and decreased under S.C. regime in the second season compared to the first season. Also, placement of nitrogen and fertilizer compaction patterns of soil affect the spike length significantly in the first season only. Where The differences in the spike length during the second season do not show consistent trend and do not differ significantly. (Table 6).

Table 6. Effect of irrigation regimes and fertilization-compaction patterns on the spike length for two successive growth seasons (2016/2017 and 2017/2018).

\begin{tabular}{|l|c|c|c|c|c|c|}
\hline Plant characters & \multicolumn{5}{|c|}{ Spike length (cm) } \\
\hline Seasons & \multicolumn{3}{|c|}{$\mathbf{2 0 1 6 / 2 0 1 7}$} & \multicolumn{3}{c|}{$\mathbf{2 0 1 7 / 2 0 1 8}$} \\
\hline Treatment type & $\begin{array}{c}\text { Field } \\
\text { Capacity }\end{array}$ & $\begin{array}{c}\text { Saturation } \\
\text { Capacity }\end{array}$ & Average & $\begin{array}{c}\text { Field Ca- } \\
\text { pacity }\end{array}$ & $\begin{array}{c}\text { Saturation } \\
\text { Capacity }\end{array}$ & Average \\
\hline F. IN UN-C.S.L. & 10.80 & 11.50 & 11.17 & 11.00 & 11.00 & 11.00 \\
\hline F. ABOVE C.S.L. & 10.20 & 11.00 & 10.58 & 11.00 & 10.33 & 10.67 \\
\hline F. BENEATH C.S.L. & 9.70 & 11.00 & 10.33 & 10.67 & 10.67 & 10.67 \\
\hline F. IN C.S.L. & 11.00 & 11.80 & 11.42 & 10.33 & 10.67 & 10.50 \\
\hline $\begin{array}{l}\text { F. ABOVE } \\
\text { UN-C.S.L. }\end{array}$ & 10.30 & 11.00 & 10.67 & 11.00 & 11.50 & 11.25 \\
\hline Average & 10.40 & 11.30 & 10.83 & 10.80 & 10.83 & 10.82 \\
\hline \multicolumn{1}{|c|}{ F } & Irrigation & Treat & Inter & Irrigation & Treat & Inter \\
\hline L.S.D.(0.05) & $*$ & $*$ & ns & Ns & ns & ns \\
\hline
\end{tabular}

\footnotetext{
* Significant at the 0.05 level, ** Significant at the 0.01 level
} 


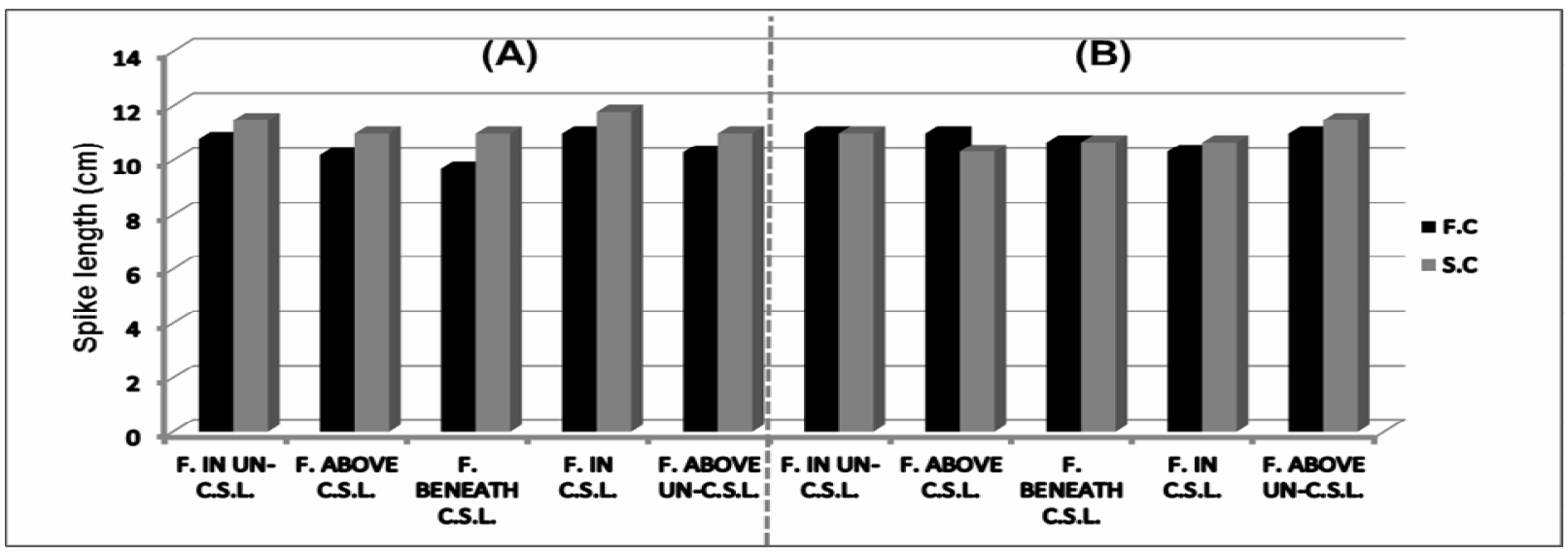

F=fertilizer . $\mathrm{C}=$ =ompacted. $\mathrm{S}=$ surface. $\mathrm{L}=$ =layer

Figure (3): The spike length at harvesting under field capacity (F.C.) and saturation capacity (S.C.) regimes, and different patterns of compactions and fertilization placement (A first season and B second season).

\section{The weight of 10-spikes}

Values of weight of 10-spikes varied 11.4 to 29.4 grams under all treatments for both two seasons (Table 7 and Figure 4) the 10-spikes weight for the irrigation regime at F.C. and S.C. as averages were 16.85 and $16.33 \mathrm{~g}$, respectively in the first growth season. The corresponding weight in the second were 26.4 and $25.65 \mathrm{~g}$. the weight of 10 -spikes under the field capacity irrigation regime was superior for most fertilization-compaction patterns in comparison to those under the saturation regime during the first growth season, except placed fertilizer above compacted surface layer (F. ABOVE C.S.L.) treatment (Figure 4).

The weights of spikes under the two growth seasons showed discrepancies, where the second season gave greater spikes weight values (average $26.04 \mathrm{~g}$ ) than the first season. (average $16.59 \mathrm{~g}$ ). Also, in the second season reduction of the differences in values of spikes weight was recorded for corresponding treatments under F.C. and S.C. regimes compared to the first season. It seems that the climatic condition, i.e. temperature and relative humidity, might affect the weights of spike. Since there are wide variations in the spike weight among the treatments, it is difficult to define a specific trend using this growth parameter.

Generally, irrigation at the field capacity combined with either placing fertilizer beneath compacted surface layer (F. BENEATH C.S.L.) or mixing fertilizer in compacted surface layer (F.IN C.S.L.) was the best combination treatment. Using the irrigation regime at F.C. minimize $\mathrm{NO}_{3}{ }^{-}-\mathrm{N}$ leaching which enhance the nitrogen uptake by plant. It is noticed that length spikes, the spike weights differed significantly in the first growth season and highly significantly in the second growth season under the placement of nitrogen and compaction patterns treatments (Table 7). In the present study, the upper 
compacted soil layer had a bulk density of $1580 \mathrm{~kg} / \mathrm{m}^{3}$ for the sandy loam soil. This is not a high bulk density to cause growth retardation for such a plant root growth (Duiker, 2004). According to this author, the bulk den- sity that restricts root growth is 1800 $\mathrm{kg} / \mathrm{m}^{3}$ and the ideal bulk density for root growth ranges between 1400 $1800 \mathrm{~kg} / \mathrm{m}^{3}$ for the sandy loam texture.

Table 7. Effect of irrigation regimes and fertilization-compaction patterns on the 10-spikes weight for two successive growth seasons $(2016 / 2017$ and 2017/2018).

\begin{tabular}{|l|c|c|c|c|c|c|}
\hline Plant characters & \multicolumn{5}{|c|}{ 10-spikes weight (g) } \\
\hline Seasons & \multicolumn{3}{|c|}{$\mathbf{2 0 1 6 / 2 0 1 7}$} & \multicolumn{3}{c|}{$\mathbf{2 0 1 7 / 2 0 1 8}$} \\
\hline Treatment type & $\begin{array}{c}\text { Field } \\
\text { Capacity }\end{array}$ & $\begin{array}{c}\text { Saturation } \\
\text { Capacity }\end{array}$ & Average & $\begin{array}{c}\text { Field Ca- } \\
\text { pacity }\end{array}$ & $\begin{array}{c}\text { Saturation } \\
\text { Capacity }\end{array}$ & Average \\
\hline F. IN UN-C.S.L. & 18.23 & 15.80 & 17.02 & 26.41 & 26.92 & 26.67 \\
\hline F. ABOVE C.S.L. & 11.37 & 19.22 & 15.29 & 20.65 & 21.71 & 21.18 \\
\hline F. BENEATH C.S.L. & 21.89 & 17.65 & 19.77 & 26.74 & 26.14 & 26.44 \\
\hline F. IN C.S.L. & 18.77 & 17.03 & 17.90 & 28.96 & 25.77 & 27.37 \\
\hline $\begin{array}{l}\text { F. ABOVE UN- } \\
\text { C.S.L. }\end{array}$ & 14.02 & 11.93 & 12.98 & 29.40 & 27.72 & 28.56 \\
\hline Average & 16.85 & 16.33 & 16.59 & 26.43 & 25.65 & 26.04 \\
\hline \multicolumn{1}{|c|}{ F } & Irrigation & Treat & Inter & Irrigation & Treat & Inter \\
\hline L.S.D.(0.05) & ns & $*$ & ns & Ns & $* *$ & ns \\
\hline
\end{tabular}

* Significant at the 0.05 level, ** Significant at the 0.01 level

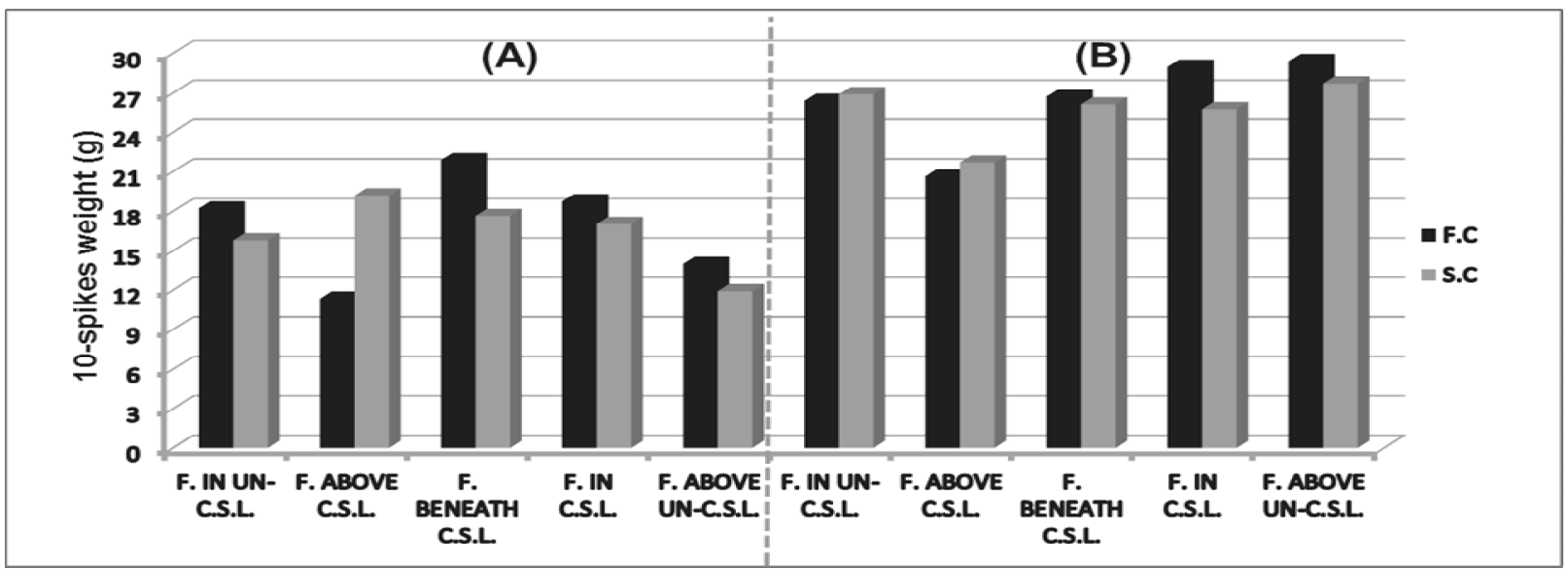

$\mathrm{F}=$ fertilizer . $\mathrm{C}=$ compacted. $\mathrm{S}=$ surface. $\mathrm{L}=$ layer

Figure (4): 10-spikes weight under field capacity (F.C.) and saturation capacity (S.C.) regimes and different patterns of compactions and fertilization placements (A first season and B second season).

\section{The total wheat biomass yield}

The data of the total yield biomass of wheat for all treatments are as shown in Figure (5). The average values of total yield using F.C. irrigation regime were $17.71-46.72 \%$ 
greater than when S.C. regime was used, except F. ABOVE C.S.L. and F. IN C.S.L treatments in the $1^{\text {st }}$ season and from 4.26 to $71.88 \%$ greater than S.C. except F. ABOVE C.S.L. treatment in the $2^{\text {nd }}$ season. These averages were 9.4 and 7.9 (ton ha ${ }^{-1}$ ) under F.C. and S.C. in the first season regimes respectively, the corresponding averages were 9.0 and 8 . (ton ha ${ }^{-1}$ ) in the second season. The F. BENEATH C.S.L. treatment under F.C regime was the best combination one in both seasons. The high total yield under F.C. irrigation regime may be attributed to the high nitrogen content in the root zone of the plant compared to corresponding content using S.C. regime. Similarly, the amount of residual $\mathrm{NO}_{3}^{-}{ }^{-} \mathrm{N}$ in soil profiles was decreased with the increasing the amount of irrigation (Wang et al., 2010). The nitrogen placement and compaction patterns did affect the total yields significantly (Table 8 ).

Table 8. Effect of irrigation regimes. $N$ fertilization and compaction patterns on the total biomass yield of wheat (ton $\mathrm{ha}^{-1}$ ) for two successive growth seasons (2016/2017 and 2017/2018).

\begin{tabular}{|l|c|c|c|c|c|c|}
\hline Plant characters & \multicolumn{5}{|c|}{ Total biomass yield (ton ha' } \\
\hline Seasons & \multicolumn{3}{|c|}{$\mathbf{2 0 1 6 / 2 0 1 7}$} \\
\hline Treatment type & $\begin{array}{c}\text { Field } \\
\text { Capacity }\end{array}$ & $\begin{array}{c}\text { Saturation } \\
\text { Capacity }\end{array}$ & Average & $\begin{array}{c}\text { Field } \\
\text { Capacity }\end{array}$ & $\begin{array}{c}\text { Saturation } \\
\text { Capacity }\end{array}$ & Average \\
\hline F. IN UN-C.S.L. & 8.90 & 9.70 & 9.30 & 9.70 & 8.90 & 9.30 \\
\hline F. ABOVE C.S.L. & 5.80 & 6.80 & 6.30 & 6.10 & 7.40 & 6.75 \\
\hline F. BENEATH C.S.L. & 12.20 & 6.50 & 9.35 & 11.00 & 6.40 & 8.70 \\
\hline F. IN C.S.L. & 10.50 & 8.60 & 9.55 & 9.40 & 8.30 & 8.85 \\
\hline F. ABOVE UN-C.S.L. & 9.60 & 7.90 & 8.75 & 9.00 & 9.40 & 9.20 \\
\hline Average & 9.4 & 7.9 & 8.65 & 9.04 & 8.08 & 8.56 \\
\hline & Irrigation & Treat & Inter & Irrigation & Treat & Inter \\
\hline \multicolumn{1}{|c|}{ F } & $*$ & $*$ & $*$ & $*$ & $* *$ & $* *$ \\
\hline \multicolumn{1}{|c|}{ L.S.D.(0.05) } & & 1.32 & 2.82 & & 1.18 & 1.41 \\
\hline
\end{tabular}

* Significant at the 0.05 level, ** Significant at the 0.01 level

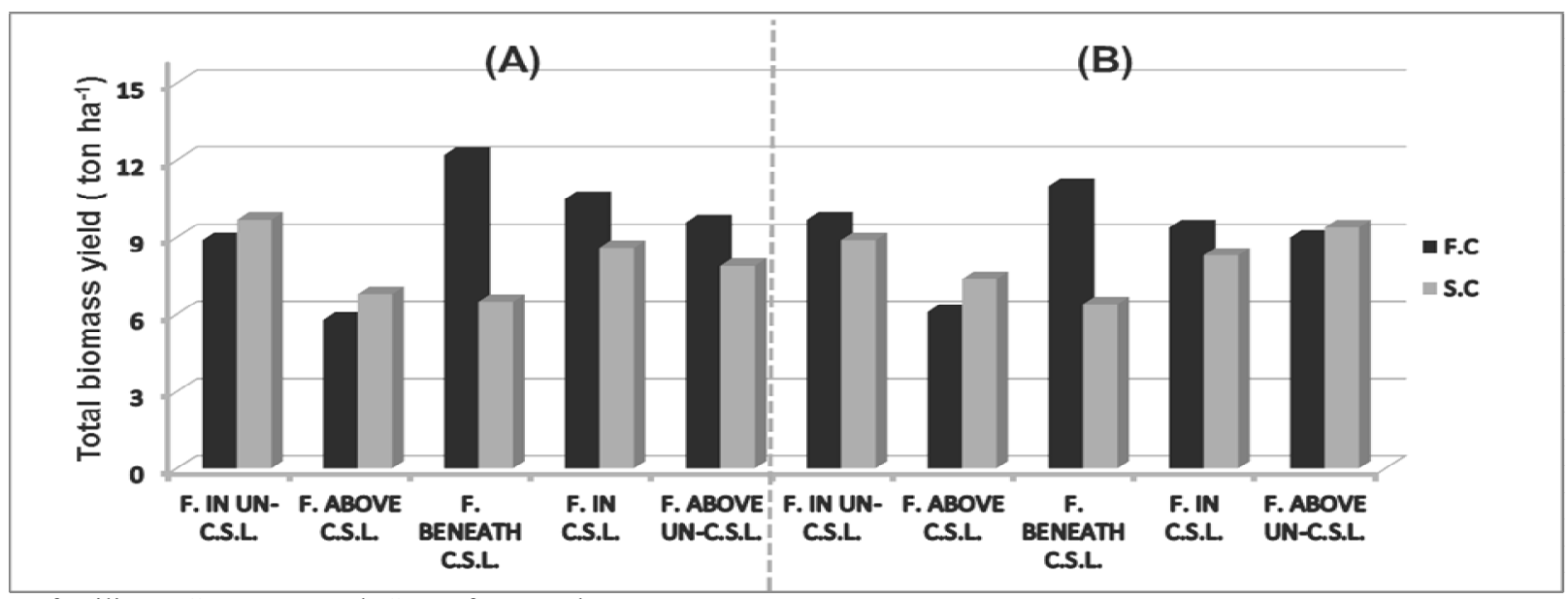

$\mathrm{F}=$ fertilizer $. \mathrm{C}=$ compacted. $\mathrm{S}=$ surface. $\mathrm{L}=$ =layer

Figure (5): total biomass yield of wheat under field capacity (F.C.) and saturation capacity (S.C.) regimes, and different patterns of compactions and nitrogen placements (A first season and B second season). 


\section{The grain yield}

The grain yields for the two irrigation regimes, the nitrogen placements and compaction patterns are shown in Figure (6). The grain yield of wheat behaved similarly to the total biomass yield but the exception of the placed fertilizer above compacted surface layer (F. ABOVE C.S.L.) treatment, occurred in the first season only. The averages were 5.9 and 3.9 (ton $\mathrm{ha}^{-1}$ ) for F.C. and S.C. irrigation regimes, respectively in the first season and 6.2 and 5.2 (ton $\mathrm{ha}^{-1}$ ) in the second season. It is obvious that the grain yield under irrigation at field capacity was superior to those under saturation capacity. where, irrigated at field capacity improved grain yield by averages of 28.2 and $84.4 \%$ across both seasons compared with irrigation at saturation capacity Similar to the results of 10-spike weight, irrigation at the field capacity combined with either placing fertilizer beneath compacted surface layer (F. BE-
NEATH C.S.L.) or mixing fertilizer in compacted surface layer (F.IN C.S.L.) was the best combination treatment. The lowest grain yield was produced from the treatment of placing fertilizer above compacted surface layer (F. ABOVE C.S.L.) in both seasons under F.C. regime. The irrigation regimes, nitrogen placement and compaction patterns affect the grain yields highly significant (Table 9). As mentioned previously, the compaction might reduce the $\mathrm{NO}_{3}{ }^{-}$$\mathrm{N}$ leaching that enhanced the grain weight. Similarly, the results of Wang et al., (2010) clearly showed that the relative high grain yield and irrigation water productivity, and relative low $\mathrm{N}$ loss were achieved with application of $221 \mathrm{~kg} \mathrm{~N} \mathrm{ha}^{-1}$ and low irrigation. Zhang et al., (2017) found that irrigation at jointing and at jointing plus and improved grain yield by averages of 12.79 and $18.65 \%$ across all the three seasons compared with no irrigation.

Table 4. Effect of irrigation regimes, $N$ fertilization and compaction patterns on grain yield of wheat (ton $\mathrm{ha}^{-1}$ ) for two successive growth seasons $(2016 / 2017$ and 2017/2018).

\begin{tabular}{|l|c|c|c|c|c|c|}
\hline Plant characters & \multicolumn{5}{|c|}{ Grain yield ( ton ha $^{-\mathbf{1}}$ ) } \\
\hline Seasons & \multicolumn{3}{|c|}{$\mathbf{2 0 1 6 / 2 0 1 7}$} & \multicolumn{3}{c|}{$\mathbf{2 0 1 7 / 2 0 1 8}$} \\
\hline Treatment type & $\begin{array}{c}\text { Field } \\
\text { Capacity }\end{array}$ & $\begin{array}{c}\text { Saturation } \\
\text { Capacity }\end{array}$ & Average & $\begin{array}{c}\text { Field } \\
\text { Capacity }\end{array}$ & $\begin{array}{c}\text { Saturation } \\
\text { Capacity }\end{array}$ & Average \\
\hline F. IN UN-C.S.L. & 5.58 & 4.80 & 5.20 & 5.60 & 5.20 & 5.40 \\
\hline F. ABOVE C.S.L. & 3.91 & 4.80 & 4.40 & 4.00 & 4.00 & 4.00 \\
\hline F. BENEATH C.S.L. & 6.41 & 2.80 & 4.60 & 7.20 & 4.00 & 5.60 \\
\hline F. IN C.S.L. & 7.24 & 4.40 & 5.80 & 7.60 & 6.40 & 7.00 \\
\hline F. ABOVE UN-C.S.L. & 6.37 & 2.80 & 4.60 & 6.80 & 6.40 & 6.60 \\
\hline Average & 83.83 & 72.99 & 78.41 & 67.24 & 62.07 & 64.66 \\
\hline \multicolumn{1}{|c|}{ F } & Irrigation & Treat & Inter & Irrigation & Treat & Inter \\
\hline L.S.D.(0.05) & $* *$ & $*$ & $* *$ & $*$ & $* *$ & $* *$ \\
\hline
\end{tabular}

\footnotetext{
* Significant at the 0.05 level, ** Significant at the 0.01 level
} 


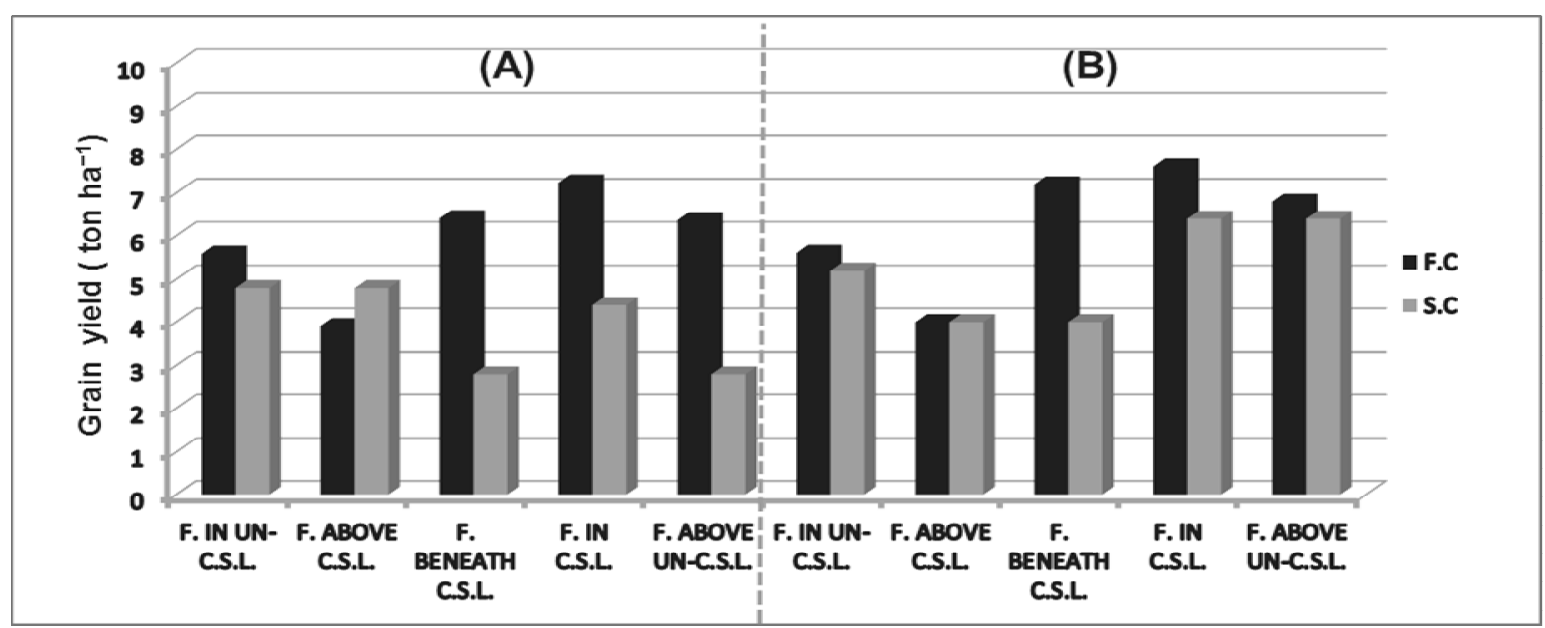

$\mathrm{F}=$ fertilizer $. \mathrm{C}=$ compacted. $\mathrm{S}=$ surface. $\mathrm{L}=$ layer

Figure (6): grain yield under field capacity (F.C.) and saturation capacity (S.C.) regimes, and different patterns of compactions and nitrogen placement (A first season and B second season).

Effect of compaction on wheat
growth

The effect of compaction on the wheat growth was evaluated using the average of growth parameter for the non-compaction condition which is calculated from F.IN UN-C.S.L. and F. ABOVE UN-C.S.L. treatments, while the average of compaction condition was obtained from F.ABOVE C.S.L., F. BENEATH C.S.L. and F.IN C.S.L treatments as shown in Table (10). For the first growth season, the germination percentages were 76.3 and $88.9 \%$ under the F.C. irrigation regime for non-compaction and compaction conditions, respectively (Table 10). The corresponding germination percentages under S.C. regime were 68.9 and $75.7 \%$. It is obvious that moderate compaction, i.e. bulk density of $1580 \mathrm{~kg} / \mathrm{m}^{3}$, enhanced the germination percentage in comparison to non-compaction condition, i.e. bulk density of $1420 \mathrm{~kg} / \mathrm{m}^{3}$. This may be due to that the compacted soil layer retained a suitable amount of water that encourages wheat seeds germination. The Plant height under the non-compaction condition was shorter than its value under compaction condition using the F.C. irrigation level in both seasons. The 10-spike weights, total biomass yield, grain yield, showed similar trend as the plant height and germination percentage. The compaction and non-compaction soil conditions showed similar spike lengths in both seasons. 
Table 10. The effect of non-compaction and compaction soil condition on wheat growth parameters for two successive growth seasons (2016/2017 and 2017/2018).

\begin{tabular}{|c|c|c|c|c|c|c|}
\hline Growth season & \multicolumn{3}{|c|}{$2016 / 2017$ (A) } & \multicolumn{3}{|c|}{$2017 / 2018$ (B) } \\
\hline Plant characters & \multicolumn{6}{|c|}{ Germination (\%) } \\
\hline Treatment type & F.C. & S.C. & Average & F.C. & S.C. & Average \\
\hline Non- compaction & 76.295 & 68.965 & 72.63 & 78.45 & 71.285 & 74.87 \\
\hline Compaction & 88.85 & 75.67 & 82.26 & 89.37 & 75.19 & 82.28 \\
\hline Plant characters & \multicolumn{6}{|c|}{ Plant height $(\mathrm{cm})$} \\
\hline Treatment type & F.C. & S.C. & Average & F.C. & S.C. & Average \\
\hline Non- compaction & 86.5 & 98.88 & 92.69 & 92.50 & 101.35 & 96.93 \\
\hline Compaction & 93.06 & 98.00 & 95.53 & 93.56 & 104.67 & 99.12 \\
\hline Plant characters & \multicolumn{6}{|c|}{ Spike length $(\mathrm{cm})$} \\
\hline Treatment type & F.C. & S.C. & Average & F.C. & S.C. & Average \\
\hline Non- compaction & 10.55 & 11.25 & 10.90 & 11.00 & 11.25 & 11.13 \\
\hline Compaction & 10.30 & 11.27 & 10.79 & 10.67 & 10.56 & 10.62 \\
\hline Plant characters & \multicolumn{6}{|c|}{10 -spikes weight (g) } \\
\hline Treatment type & F.C. & S.C. & Average & F.C. & S.C. & Average \\
\hline Non- compaction & 15.06 & 17.58 & 16.32 & 23.53 & 24.32 & 23.92 \\
\hline Compaction & 18.24 & 15.35 & 16.84 & 28.36 & 26.54 & 27.45 \\
\hline Plant characters & \multicolumn{6}{|c|}{ Total biomass yield $\left(\right.$ ton $\left.\mathrm{ha}^{-1}\right)$} \\
\hline Treatment type & F.C. & S.C. & Average & F.C. & S.C. & Average \\
\hline Non- compaction & 9.5 & 7.3 & 8.4 & 8.8 & 7.4 & 8.1 \\
\hline Compaction & 9.3 & 8.8 & 9 & 9.4 & 9.2 & 9.3 \\
\hline Plant characters & \multicolumn{6}{|c|}{ Grain yield $\left(\right.$ ton ha $\left.{ }^{-1}\right)$} \\
\hline Treatment type & F.C. & S.C. & Average & F.C. & S.C. & Average \\
\hline Non- compaction & 6 & 3.8 & 4.9 & 6.2 & 5.8 & 6 \\
\hline Compaction & 5.9 & 4 & 4.9 & 6.3 & 4.8 & 5.5 \\
\hline
\end{tabular}

\section{Conclusion}

Lysimeter experiments were conducted for growth wheat plants (Triticum aestivum L.) using two irrigation regimes, field capacity (F.C.) and saturation capacity (S.C.), and five ammonium nitrate placements combined with moderate compacted/non-compacted surface soil layer. Sandy loam soil was packed in the lysimeters. The upper $0.15 \mathrm{~m}$ soil layer was compacted moderately to $1580 \mathrm{Kg} / \mathrm{m} 3$ in some lysimeters while the rest of soil layer $(0.40-\mathrm{m}$ deep) was packed at $1420 \mathrm{~kg} / \mathrm{m}^{3}$. Some growth parameter growth parameters were measured for evaluation the irrigation regimes, nitrate placement and surface soil compaction. the result showed that growth parameters such as germination percentage, total and grain yield improved under irrigation at filed capacity regime. All the studied growth parameter showed moderate compaction of the surface sandy loam soil layer is preferred compared to the un-compacted soil layer except the length of pike which showed similer values for compacted and un-compacted soil. So, it is recommended to use irrigation at filed capacity and the moderate compaction of surface layer when cultivate wheat in sandy loam soil.

\section{References}

Al-Molhem, Y.A. (2016). Effect of Irrigation regime on growth and yield of wheat (Triticum aestivum L.) under alhasa condition. Mansoura Univ, 7,665-668. 
Ashraf, C.M., \& Abu-Shakra, S. (1978). Wheat Seed Germination under Low Temperature and Moisture Stress 1. Agronomy Journal, 70(1), 135-139.

Atwell, B. J. (1990). The effect of soil compaction on wheat during early tillering1. Growth, Development and Root Structure. New Phytol. 115, 29-35.

Bakken, L. R., Børresen, T., \& Njøs, A. (1987). Effect of soil compaction by tractor traffic on soil structure, denitrification, and yield of wheat (Triticum aestivum L.). Journal of Soil Science, 38(3), 541-552.

Bar-Yosef, B. (1999). Advances in fertigation. In Advances in agronomy (Vol. 65, pp. 1-77). Elsevier.

Doorenbos, J., \& Kassam, A. H. (1979). Yield response to water. Irrigation and Drainage Paper, 33, 257.

Duiker, S. W. (2004). Effects of soil compaction. The Pennsylvania State University.

Evans, L. T., Wardlaw, I. F., \& Fischer, R. A. (1975). Wheat. p. 101--149. LT Evans (ed.) Crop physiology. Cambridge Univ.

Geerts, S., \& Raes, D. (2009). Deficit irrigation as an on-farm strategy to maximize crop water productivity in dry areas. Agricultural Water Management, 96(9), 1275-1284.

Gomez, K. A., Gomez, K. A., \& Gomez, A.A. (1984). Statistical procedures for agricultural research. John Wiley \& Sons.

Ishaq, M., Hassan, A., Saeed, M., Ibrahim, M., \& Lal, R. (2001). Subsoil compaction effects on crops in Punjab, Pakistan: I. Soil physical properties and crop yield. Soil and Tillage Research, 59(12), 57-65.

Kharrou, M. H., Er-Raki, S., Chehbouni, A., Duchemin, B., Simonneaux, V., LePage, M., \& Jarlan, L.
(2011). Water use efficiency and yield of winter wheat under different irrigation regimes in a semi-arid region. Agricultural Sciences in China, 2(03), 273-282.

Lipiec, J., Arvidsson, J., \& Murer, E. (2003). Review of modelling crop growth, movement of water and chemicals in relation to topsoil and subsoil compaction. Soil and Tillage Research, 73(1-2), 15-29.

Mohamed, M. M. E. (2007). Water requirement of wheat and sunflower under different irrigation system at Assiut. M. Sc. Fac. Agric., Assiut, Univ. Egypt.

Oussible, M., Crookston, R. K., \& Larson, W.E. (1992). Subsurface compaction reduces the root and shoot growth and grain yield of wheat. Agronomy Journal, 84(1), 34-38.

Pengthamkeerati, P., Motavalli, P. P., Kremer, R. J., \& Anderson, S. H. (2006). Soil compaction and poultry litter effects on factors affecting nitrogen availability in a claypan soil. Soil and Tillage Research, 91(1-2), 109-119.

Saleem, M., Shafi, M., Bakht, J., \& Anwar, S. (2007). Response of wheat varieties to water regime. Sarhad Journal of Agriculture, 23(1), 115.

Shirazi, S.M., Z.Yusop,N. H. Zardari, \& Ismail, Z. (2014). Effect of Irrigation Regimes and Nitrogen Levels on the Growth and Yield of Wheat. Hindawi Publishing Corporation Advances in Agriculture Volume 2014, Article ID 250874, 6 pages

Tadayon, M. R., Ebrahimi, R., \& Tadayyon, A. (2012). Increased water productivity of wheat under supplemental irrigation and nitrogen application in a semi-arid region. J. Agric. Sci. and Tech., 14:995-1003. 
Wang, Q., Li, F., Zhao, L., Zhang, E., Shi, S., Zhao, W., Vance, M. M. (2010). Effects of irrigation and nitrogen application rates on nitrate nitrogen distribution and fertilizer nitrogen loss, wheat yield and nitrogen uptake on a recently reclaimed sandy farmland. Plant and Soil, 337(1-2), 325-339.
Zhang, P., Ma, G., Wang, C., Lu, H., Li, S., Xie, Y., Guo, T. (2017). Effect of irrigation and nitrogen application on grain amino acid composition and protein quality in winter wheat. PloS One, 12(6), e0178494. 
تأثير مستويات الري و أنماط وضع النيتروجين مع دمج التربة على نمو القمح (Triticum aestivum L.)

محمود حفظي محمد عبدالعزيز، ابراهيم نصار نصار، محسن عبد المنعم جامع و سلمان عبدالله حسن سلمي

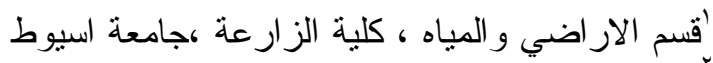

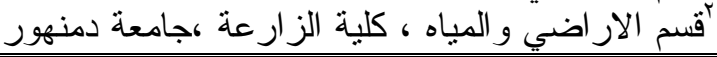

تعتبر إدارة الري ونمط استخدام النيتزوجين المرتبط بانضغاط التزبة من العو امل المؤثزة

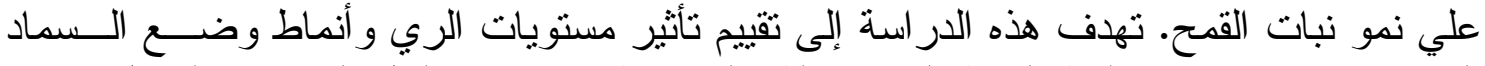

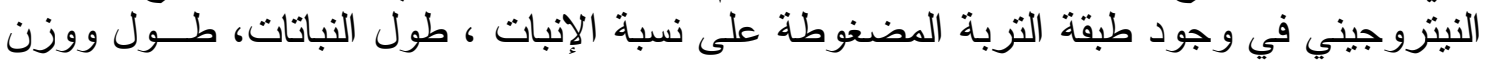
السنابل ، المحصول الكلي و محصول الحبوب للقمح (Triticum aestivum L.) .

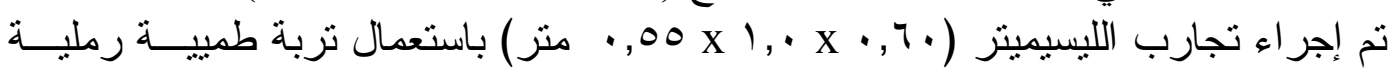

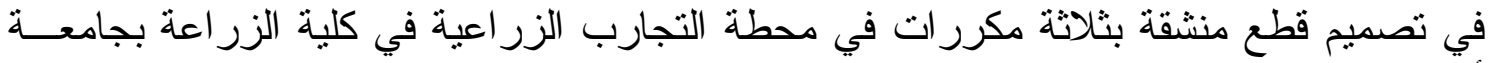

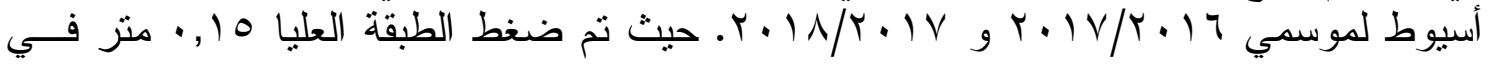

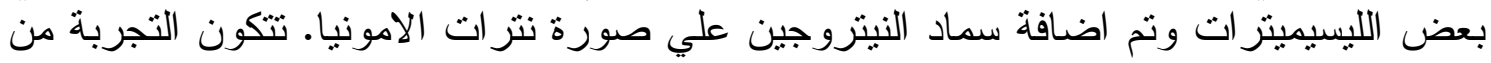

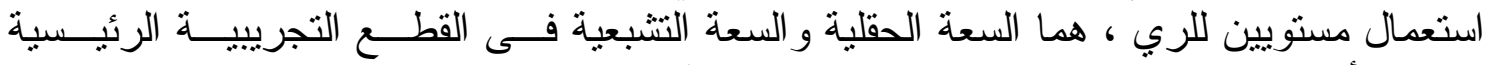

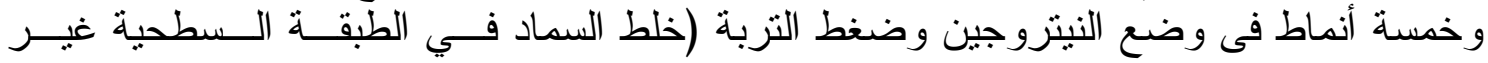

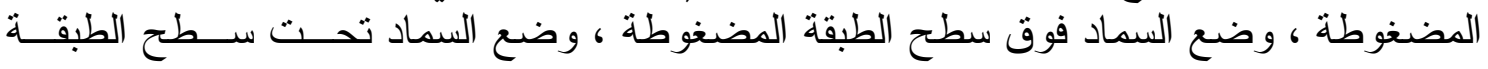

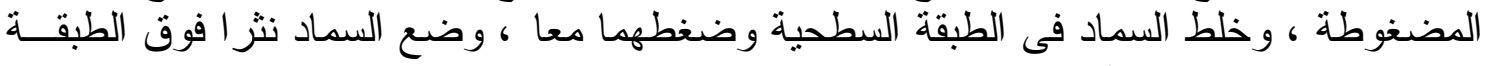
السطحية غير المضغوط) في القطع الفر عية.

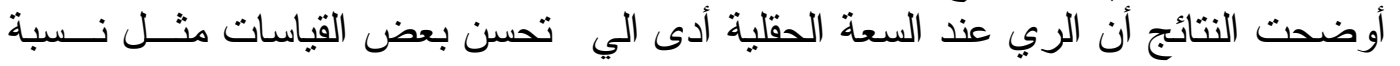

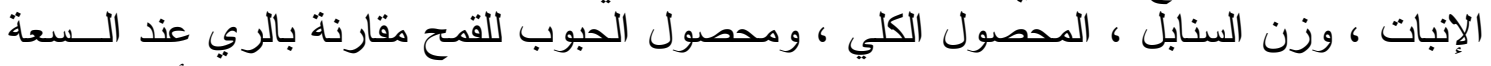

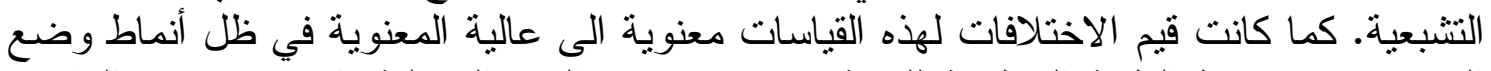

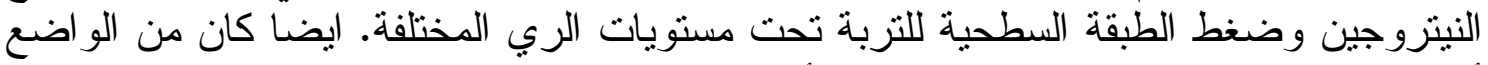

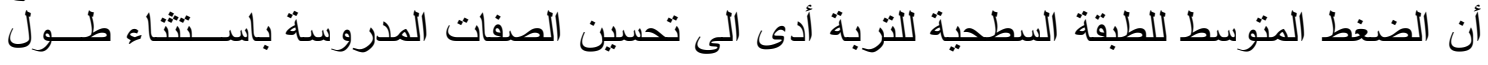

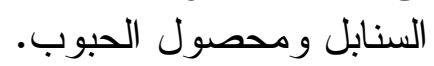

بصفة عامة تأثرت بعض معايير النمو للقمح ايجابيا بشكل ملحوظ في ظل وجود الطبقــة

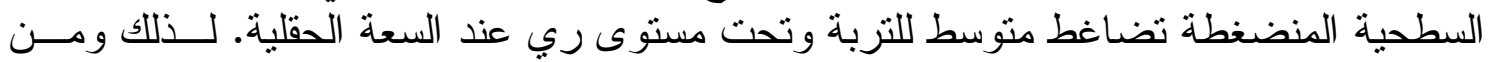

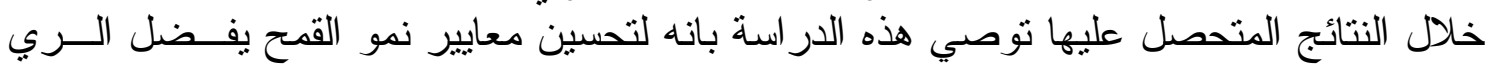

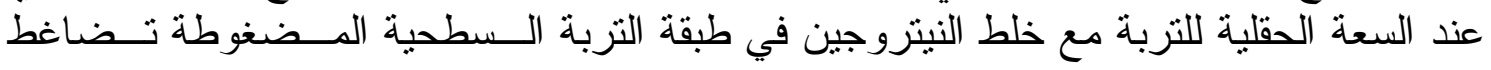
متوسط. الكلمات المفتاحية : القمح ، الليسيميتز ، الري ، انضغاط السطح وصفات النمو 